\title{
Effect of replacement of forage sorghum silage with biomass sorghum silage in diets for dairy heifers
}

\section{Efeito da substituição da silagem de sorgo forrageiro por silagem de sorgo biomassa em dietas para novilhas leiteiras}

\author{
Fausto Expedito de Queiroz; Vicente Ribeiro Rocha Júnior²; Flávio Pinto \\ Monção3*; João Paulo Sampaio Rigueira²; Fredson Vieira e Silva²; Amanda Maria \\ Silva Alencar ${ }^{1}$; Matheus Wilson Silva Cordeiro'; Virgílio Mesquita Gomes²; Cinara \\ da Cunha Siqueira Carvalho2; Maria Dulcinéia da Costa²
}

\section{Highlights}

The BRS 716 silage presents potential for forage production in the semiarid region.

The biomass sorghum BRS 716 is recommended for ruminants.

The BRS 716 silage can replace up to $100 \%$ the FS silage in diets for dairy heifers.

\begin{abstract}
This trial aimed to analyze the replacement of forage sorghum silage (FS silage) with biomass sorghum silage (BRS 716 silage) in diets for heifers $3 / 4$ Holstein $\times 1 / 4$ Zebu on their nutrient intake and digestibility, nitrogen balance, microbial production, feeding behavior, and animal performance. Eight heifers with average age $18 \pm 4$ months (mo) and average body weight (BW) $271 \pm 57 \mathrm{~kg}$ were used. The experimental design was double-Latin square, $4 \times 4$, being four diets, four experimental periods and four animals. Four experimental diets with $0,33,67$ and $100 \%$ substitution of forage sorghum silage with biomass sorghum silage were used. The roughage:concentrate ratio in the total dry matter (DM) of the diets was 75:25. The fraction "b" of DM was higher in the BRS 716 silage. There was no difference ( $p>0.05)$ for dry matter intake ( $D M l ; p=0.45)$ and total digestible nutrients intake $(p=0.76$ ). The dry matter digestibility (DMD), crude protein, ether extract and neutral detergent fiber increased linearly with the inclusion of BRS 716 silage. The feeding times, ruminating and idle have not been changed ( $p>0.05$ ). The replacement of FS silage with BRS 716 silage did not modify the average daily weight gain (ADG; $p>0.05$; mean $1.30 \pm 0.025 \mathrm{~kg}$ ). Biomass sorghum silage can replace up

1 Students of Animal Science Master's Program, Universidade Estadual de Montes Claros, UNIMONTES, Janaúba, MG, Brazil. E-mail: faustozootecnia@hotmail.com; amandaalencar604@gmail.com; matheuszoow@gmail.com

2 Profs. Drs., Graduate Program in Animal Science (Master), UNIMONTES, Janaúba, MG, Brazil. E-mail: vicente.rocha@ unimontes.br; joao.rigueira@unimontes.br; fredson.silva@unimontes.br; cinara.carvalho@unimontes.br; dulcineia. costa@unimontes.br

3 Prof. and Researcher PNPD/Capes, Graduate Program in Animal Science (Master), UNIMONTES, Janaúba, MG, Brazil. E-mail: moncaomoncao@yahoo.com.br

* Author for correspondence
\end{abstract}

Received: May 31, 2021 - Approved: Oct. 14, 2021 
to $100 \%$ forage sorghum silage in the diets of $3 / 4$ Holstein $\times 1 / 4$ Zebu heifers.

Key words: Animal performance. BRS 716. Digestibility. Intake. Semiarid.

\section{Resumo}

Objetivou-se analisar a substituição da silagem de sorgo forrageiro (silagem FS) pela silagem de sorgo biomassa (silagem BRS 716) em dietas para novilhas $3 / 4$ Holandês $\times 1 / 4$ Zebu sobre o consumo e digestibilidade de nutrientes, balanço de nitrogênio, produção microbiana, comportamento alimentar e desempenho animal. Foram utilizadas oito novilhas com idade média de $18 \pm 4$ meses e peso corporal (PC) médio de $271 \pm 57 \mathrm{~kg}$. O delineamento experimental foi o quadrado latino duplo, $4 \times 4$, sendo quatro dietas, quatro períodos experimentais e quatro animais. Foram utilizadas quatro dietas experimentais com 0, 33, 67 e $100 \%$ de substituição da silagem de sorgo forrageiro pela silagem de sorgo biomassa. A relação volumoso: concentrado na matéria seca total (MS) das dietas foi de 75:25. A fração "b" da MS foi maior na silagem BRS 716. Não houve diferença $(p>0,05)$ para consumo de matéria seca (CMS; $p=0,45)$ e consumo de nutrientes digestíveis totais $(p=0,76)$. A digestibilidade da matéria seca (DMS), proteína bruta, extrato etéreo e fibra em detergente neutro aumentaram linearmente com a inclusão da silagem BRS 716. Os tempos de alimentação, ruminação e ócio não foram alterados ( $p>0,05)$. A substituição da silagem FS pela silagem de BRS 716 não alterou o ganho em peso médio diário (GMD; $p>0,05 ;$ média 1,30 $\pm 0,025 \mathrm{~kg}$ ). A silagem de sorgo biomassa pode substituir até $100 \%$ a silagem de sorgo forrageiro na dieta de novilhas $3 / 4$ Holandês $\times 1 / 4$ Zebu.

Palavras-chave: Desempenho animal. BRS 716. Digestibilidade. Ingestão. Semiárido.

\section{Introduction}

Sorghum (Sorghum bicolor (L.) Moench), for being it is an annual crop and has a high mass yield and good nutritional value is widely cultivated in various regions of the world. According to the Food and Agriculture Organization [FAO; FAOSTAT] (2020), the top sorghum producing countries have been the United States, Nigeria and Sudan. The Brazil is the fifth largest producer in the world and the first in Latin America. In Brazil, most of the sorghum grown is for animal feed, especially in regions with low rainfall (Ramos et al., 2021; Queiroz et al., 2021; Souza et al., 2021).

In semiarid regions, due to the irregularity of the rains and the long periods of drought, the cultivation of forage sorghum for silage has been constant (L. D. A. Borges et al., 2019; Costa et al., 2020; Queiroz et al., 2021). However, mass yield and plant efficiency are affected by a number of factors, such as variation in soil fertility, low rainfall and distribution of rainfall, not showing all its productive potential and interfering with its nutritional quality (Pino \& Heinrichs, 2017). Furthermore, to raising the cost of silage production. Forage sorghum (i.e. Volumax) has traditionally been grown throughout Brazil for production of silage and grains for ruminants, because it is drought resistant and has reasonable dry matter yield (DMY) (10-20 t/ha DM) with good nutritional value (Castro et al., 2015; Almeida et al., 2019).

In view of the growing demand for biomass for power generation, required by the thermoelectric and sugar-alcohol industries distributed in Brazil, Embrapa Milho e Sorgo 
has developed biomass sorghum hybrids. Among the hybrid highlights the BRS 716, photoperiod sensitive, with higher potential yield, 50 t/ha of dry matter per cycle (6 mo), and high structural growth characteristic (Castro et al., 2015; Almeida et al., 2019). Moreover, it is tolerant to water deficit and lodging. The biomass sorghum BRS 716 has favorable characteristics for use as a source of roughage for animals (Ramos et al., 2021). However, there are no reports in the literature of this use. According to Monção et al. $(2019 a, b)$, plants with high growth (up to five meters in height) show changes in fibrous fractions, compromising their digestibility.

In Brazil, the effectiveness of milk yield systems is dependent on replacement heifers, having an important share in the cost of production. Thus, the creation of replacement heifers is essential to ensure adequate growth so that these animals have early age at first calving, at low cost. Moreover, that they can readily replace cows discarded from the herd after lactation, since the rearing represents 20 to $25 \%$ of the cost in the dairy activity (Mohd, Steeneveld, Mourits, \& Hogeveen, 2015; Williams et al., 2019). Thus, an alternative would be the use of a source of roughage with less cost, good nutritional value and acceptability by the animal. Thus, we hypothesized that FS silage can be replaced up to $100 \%$ with BRS 716 silage in the diet of dairy heifers without changing the nutritional parameters and performance of the animals.

Based on the above, the objective was to evaluate the replacement of FS silage with BRS 716 silage in the diet of $3 / 4$ Holstein x $1 / 4$ Zebu heifers on their nutrient intake and digestibility, nitrogen balance, microbial production, feeding behavior, and body performance.

\section{Materials and Methods}

Procedures involving animals were approved by the Committee on Animal Research and Ethics, under the protocol number $173 / 2018$ of the State University of Montes Claros.

The trial was conducted at the Laboratory of Forage and Experimental Farm at the State University of Montes Claros (Unimontes), Janaúba Campus (MG, Brazil) (Geographic coordinates: 1552'38" South, $43^{\circ} 20^{\prime} 05^{\prime \prime}$ West). The duration of the experiment was $84 \mathrm{~d}$, with $21 \mathrm{~d}$-periods being $17 \mathrm{~d}$ of adaptation to diets and the last $4 \mathrm{~d}$ for sampling. The experimental design was simultaneous in two $4 \times 4$ Latin squares, being four diets, four experimental periods and four animals. Heifers were housed in individual covered stalls $\left(16 \mathrm{~m}^{2}\right)$ with concrete floor, equipped with individual concrete troughs for feeding and automatic drinkers.

The study included eight $3 / 4$ Holstein $x$ $1 / 4$ Zebu ( $1 / 2$ Nellore $x 1 / 2$ Gyr) heifers with an initial BW of $271 \pm 57 \mathrm{~kg}$ (mean \pm SEM), with a mean age of 18 mo. Four experimental diets were used, constituting the following treatments: Treatment 1 - 100\% FS silage composing the roughage fraction of the diet; Treatment 2 - 33\% BRS 716 silage and 67\% FS silage; Treatment 3 - 67\% BRS 716 silage and $33 \%$ FS silage; Treatment $4-100 \%$ BRS 716 silage. The concentrate was the same in all diets. The roughage:concentrate ratio in the total DM of the diets was 75:25. The diets were formulated to be isoproteic and supplied to heifers twice a day, at 8:00 am and 2:00 pm, in a complete diet system, total mixed ration (TMR). 
The sorghum used for silage production was Sorghum bicolor (L.) Moench cv. Volumax and Sorghum bicolor (L.) Moench cV. BRS 716 biomass, grown at Experimental Farm. Sorghum was planted in soil clayey eutrophic red-yellow latosol with the following chemical characteristics: $\mathrm{pH}$ in $\mathrm{CaCl}_{2}, 6.3$; $\mathrm{P}$ (Mehlich), $21.2 \mathrm{mg} \mathrm{dm} 3$; K (Mehlich), $110 \mathrm{mg} \mathrm{dm} 3$; $\mathrm{Na}$ (Mehlich), 0.3 cmolc dm ${ }^{3} ; \mathrm{Ca}^{2+}, 3.9$ cmolc. $\mathrm{dm}^{3} ; \mathrm{Mg}^{2+}, 1.1 \mathrm{cmolc} \mathrm{dm}{ }^{3} ; \mathrm{Al}^{3+}, 0.0$ cmolc. $\mathrm{dm}^{3} ;$ $\mathrm{H}+\mathrm{Al}(0.5 \mathrm{~mol}$. L calcium acetate), $1.2 \mathrm{cmolc}$ $\mathrm{dm}^{3}$; sum of bases of $5.5 \mathrm{cmolc} \mathrm{dm}^{3}$; cation

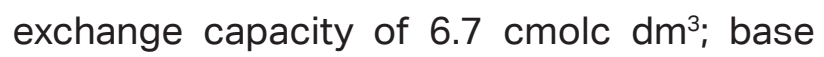
saturation (V) of $82 \%$. The soil was meshed and leveled mechanically using harrows attached to the tractor (New Holland TL 75 tractor; New Holland Agriculture ${ }^{\circledR}$, Paranavaí - PR, Brazil). During planting $250 \mathrm{~kg} \mathrm{ha}^{-1}$ of monoammonium phosphate was used. Overhead irrigation was used (flow rate $1.25 \mathrm{~m}^{3} / \mathrm{hour} ; 17.36 \mathrm{~mm} / \mathrm{h} ; 20$ meters range (radius)) for two hours. Atrazine herbicide was used to control invasive plants. The Volumax sorghum and BRS-716 biomass was managed and harvested 110 and 160 days after planting (Souza et al., 2021), respectively. The dry matter yield of Volumax sorghum was $15.90 \mathrm{t} / \mathrm{ha}$ and the biomass sorghum, $29.70 \mathrm{t} /$ ha. For sorghum silage, the surface type silo was used.

On the 18th, 19th and 20th day of each experimental period, samples of the feed supplied, leftovers (refusals) and feces were collected in the morning and stored in a freezer, $-20^{\circ} \mathrm{C}$. Fresh samples (ingredients, leftovers and feces) were dried at $55^{\circ} \mathrm{C}$ for 72 $\mathrm{h}$ in a forced-air oven to determine dry matter concentration then ground to pass through at 1 and 2-mm screen in a Wiley mill (MA340, Marconi, Piracicaba, Brazil) for analyzes of chemical composition and in situ degradability, respectively.

The ingredients, leftovers and feces were analyzed for DM content (INCT-CA G-001/1 and G-003/1), crude protein $(N \times 6.25$; Kjeldahl method; INCT-CA N-001/1), ether extract (INCT-CA G-005/1), organic matter and ash (INCT-CA M-001/1), neutral detergent fiber (TE-149 fiber analyzer, Tecnal Laboratory Equipment Inc., Piracicaba, Brazil; INCT-CA F-002/1) and acid detergent fiber (INCT-CA F-003/1), with corrections for ashes (INCTCA M-002/1) and proteins (INCT-CA N-004/1) using $\alpha$-amylase and without sodium sulfite according to Detmann et al. (2012). The neutral detergent insoluble nitrogen (NDIN) contents and acid detergent insoluble nitrogen (ADIN), lignin (INCT-CA F-007/1), indigestible neutral detergent fiber (iNDF) (INCT-CA F-008/1) and non-fibrous carbohydrates, following the recommendations described in Detmann et al. (2012). The content of total digestible nutrients in the diets was estimated according to National Research Council [NRC] (2001). The proportion of ingredients and the chemical composition of the diets and ingredients used during the experimental period can be seen in Tables 1 and 2. 
Table 1

Ingredients and chemical composition of experimental diets

\begin{tabular}{|c|c|c|c|c|}
\hline \multirow{2}{*}{ Item } & \multicolumn{4}{|c|}{ Treatment $^{\mathrm{a}}$} \\
\hline & 0 & 33 & 67 & 100 \\
\hline \multicolumn{5}{|l|}{ Ingredient, g/kg DM } \\
\hline Forage sorghum silage & 738.38 & 494.07 & 243.05 & 0.00 \\
\hline Biomass sorghum silage & 0.00 & 243.35 & 493.46 & 735.58 \\
\hline Ground corn & 172.45 & 172.45 & 172.45 & 172.45 \\
\hline Soybean meal & 72.55 & 72.55 & 72.55 & 72.55 \\
\hline Urea/Ammonium sulfate $(9: 1)$ & 11.60 & 12.60 & 13.50 & 14.40 \\
\hline Mineral mix ${ }^{1}$ & 5.00 & 5.00 & 5.00 & 5.00 \\
\hline \multicolumn{5}{|l|}{ Chemical composition, $\mathrm{g} / \mathrm{kg}$} \\
\hline Dry matter, g/kg as-fed & 481.73 & 474.58 & 467.12 & 459.92 \\
\hline Ash & 90.97 & 87.00 & 82.79 & 78.74 \\
\hline Crude protein & 124.14 & 124.35 & 124.23 & 124.19 \\
\hline Ether extract & 30.42 & 29.27 & 28.09 & 26.95 \\
\hline Total carbohydrates & 777.90 & 785.44 & 793.24 & 800.76 \\
\hline Non-fibrous carbohydrates & 328.69 & 327.74 & 326.77 & 325.83 \\
\hline Neutral detergent fiber & 534.19 & 540.28 & 546.57 & 552.65 \\
\hline Neutral detergent fiber corrected for ash and protein & 494.47 & 500.59 & 506.92 & 513.04 \\
\hline Indigestible neutral detergent fiber & 209.21 & 195.64 & 181.71 & 168.21 \\
\hline Acid detergent fiber & 248.88 & 195.91 & 180.30 & 165.19 \\
\hline Lignin & 54.43 & 59.53 & 64.77 & 69.85 \\
\hline Total digestible nutrients ${ }^{2}$ & 613.93 & 623.53 & 633.42 & 642.99 \\
\hline Digestible energy, Mcal/kg & 2.48 & 2.53 & 2.63 & 2.54 \\
\hline Metabolizable energy, Mcal/kg & 2.16 & 2.11 & 2.21 & 2.11 \\
\hline
\end{tabular}

a Control diet (0) with forage sorghum silage and biomass sorghum silage replacing forage sorghum silage at 33,67 and $100 \%$.

${ }^{1}$ Each $\mathrm{kg}$ contained: calcium (128 g; min), phosphorus (100 g; min), sodium (120 g; min), magnesium (15 g), sulfur (33 g), cobalt (135 mg), iron (938 mg), iodine (160 mg), manganese (1800 mg), selenium (34 mg), zinc (5760 mg), fluorine (1000 mg). ${ }^{2}$ Estimated according to NRC (2001).

Intake and Apparent nutrient digestibility

The DM and nutrient intake ( $\mathrm{Nl}$; $\mathrm{kg} / \mathrm{d})$ were calculated by the difference between the nutrient offered $(\mathrm{kg} / \mathrm{d})$ and refused $(\mathrm{kg} / \mathrm{d})$. The apparent total-tract digestibility of DM and nutrients was calculated as follows:

DM digestibility $(\%)=\frac{[(\mathrm{DMI}-\mathrm{FE}) \times 100]}{D M I}$,
Nutrient digestibility $(\%)=[(\mathrm{NI}-\mathrm{NE}) / \mathrm{NI}] \times 100$, where, FE is the fecal excretion calculated as follows:

$\mathrm{FE}\left(\frac{\mathrm{kg}}{\mathrm{d}}\right)=[\mathrm{iNDF}$ intake $(\mathrm{kg} / \mathrm{d})] /$ iNDF in feces $(\mathrm{kg} / \mathrm{kg})$ and nutrient excretion (NE; g/kg) is $F E(\mathrm{~kg} / \mathrm{d}) \times N C F(\mathrm{~g} / \mathrm{kg})$, where NCF is nutrient concentration in feces. 
Table 2

Chemical composition of ingredients

\begin{tabular}{lcccc} 
Item & $\begin{array}{c}\text { Forage } \\
\text { sorghum silage }\end{array}$ & $\begin{array}{c}\text { Biomass } \\
\text { sorghum silage } \\
\text { g/kg DM }\end{array}$ & $\begin{array}{c}\text { Ground } \\
\text { corn }\end{array}$ & $\begin{array}{c}\text { Soybean } \\
\text { meal }\end{array}$ \\
\hline Dry matter, g/kg as-fed & 330.10 & 297.90 & 898.10 & 916.80 \\
\hline Ash & 90.20 & 70.10 & 17.60 & 65.30 \\
\hline Organic matter & 909.80 & 929.90 & 982.40 & 934.70 \\
\hline Crude protein & 61.30 & 51.70 & 77.60 & 487.10 \\
\hline Ether extract & 31.50 & 26.90 & 34.70 & 16.20 \\
\hline Total carbohydrates & 817.00 & 851.20 & 845.30 & 397.90 \\
\hline Non-fibrous carbohydrates & 261.00 & 258.10 & 678.40 & 261.70 \\
\hline Neutral detergent fiber & 656.80 & 684.40 & 185.80 & 236.80 \\
\hline NDFap ${ }^{1}$ & 617.30 & 644.90 & 166.90 & 136.20 \\
\hline iNDF $^{2}$ & 270.40 & 215.70 & 49.60 & 13.70 \\
\hline Acid detergent fiber & 270.40 & 209.00 & 30.10 & 86.30 \\
\hline Neutral detergent insoluble nitrogen & 5.16 & 4.71 & 1.52 & 5.31 \\
\hline Acid detergent insoluble nitrogen & 3.29 & 3.11 & 0.25 & 2.46 \\
\hline Lignin $^{\text {Total digestible nutrients }}{ }^{3}$ & 65.10 & 86.30 & 29.00 & 18.80 \\
\hline Total & 550.60 & 592.20 & 861.10 & 811.60
\end{tabular}

${ }^{1}$ NDFap - Neutral detergent fiber corrected for ash and protein

2 iNDF - Indigestible neutral detergent fiber

${ }^{3}$ Estimated according to NRC (2001).

To estimate the metabolizable energy intake (MEI), DMI was taken into account. To estimate the digestible energy (DE), metabolizable (ME) and net weight gain values, equations mentioned in the NRC (2001) were used. The efficiency of using energy from the diet for weight gain was calculated by the ratio of the net energy gain to the net energy intake. The evaluation of feeding costs was performed according to L. D. A. Borges et al. (2019). The costs per kg of dry matter of the diet ingredients were: sorghum forage silage, \$0.06, sorghum biomass BRS 716 silage $\$ 0.02$ and concentrate $\$ 0.28$. The amounts were expressed in US dollars, considering the $\mathrm{R}$ $\$ 5.35$ ratio for each $\$ 1.0$.
Spot urine samples were obtained on the 18th day of each experimental period, approximately four hours after feeding in the morning, during spontaneous urination. 10 $\mathrm{mL}$ aliquots of this sample were filtered and immediately diluted in $40 \mathrm{~mL}$ of $0.036 \mathrm{~N} \mathrm{H}_{2} \mathrm{SO}_{4}$ for further analysis of creatinine. These aliquots were stored in plastic flasks, identified and frozen for further analysis and quantification of urea, total nitrogen, creatinine, uric acid and allantoin.

Blood samples were collected on the first and last day of each experimental period, via puncture of the jugular vein, using $5 \mathrm{~mL}$ test tubes (Vacutainer ${ }^{\mathrm{TM}}$ ) with EDTA (anticoagulant). 
Immediately, centrifugation was carried out at 5,000 rpm for 15 minutes and, subsequently, plasma samples were taken, which were packed in eppendorf and stored at $-15^{\circ} \mathrm{C}$ for further analysis of urea.

The concentrations of urea, creatinine and uric acid in the urine and urea in the plasma were estimated using commercial kits (Bioclin, Belo Horizonte, Minas Geras, Brazil). The conversion of urea values into urea nitrogen was performed by multiplying the values obtained by the factor 0.4667 .

The urinary contents of allantoin and uric acid were estimated by colorimetric methods, as specified by Chen and Gomes (1992), and the total nitrogen content estimated by the Kjeldhal method (Detmann et al., 2012). The balance of nitrogen compounds (Nitrogen balance, g/day) was calculated as: $\mathrm{N}$ retained $(\mathrm{g})=\{\mathrm{N}$ ingested $(\mathrm{g})-\mathrm{N}$ fecal $(\mathrm{g})-\mathrm{N}$ urine $(\mathrm{g})\}$, where: Nitrogen balance $=$ nitrogen retained in the animal's organism; $\mathrm{N}$ ingested $=$ nitrogen ingested by the animal; $\mathrm{N}$ fecal $=$ nitrogen excreted in feces and $\mathrm{N}$ urine $=$ nitrogen excreted in urine. The excretion of creatinine ( $\mathrm{mg} / \mathrm{kg}$ BW) used to estimate the urinary volume through the spot samples was obtained for each animal, according to the equation described by Chizzotti, Valadares, Valadares, Chizzotti and Tedeschi (2008): EC $=\{32.27-0.01093 \times$ BW $\}$, where: $E C=$ daily excretion of creatinine ( $\mathrm{mg} / \mathrm{kg}$ BW). Since, in growing animals, the percentage of muscle tissue varies according to body weight and, consequently, the excretion of creatinine ( $\mathrm{mg} / \mathrm{kg}$ of BW) can be altered. The total daily urinary volume was estimated by dividing the daily urinary excretions of creatinine by the observed values of creatinine concentration in the urine.
The excretion of total purines was estimated by the sum of the amounts of allantoin and uric acid excreted in the urine and the amount of absorbed purines (mmol/ day), by the excretion of total purines (mmol/ day), by means of equation proposed by Verbic, Chen and Macleod (1990):AP $=\{($ total purines $-0.385 \times \mathrm{BW} 0.75) / 0.85\}$, where: $\mathrm{AP}=$ absorbed purines $(\mathrm{mmol} / \mathrm{day}) ; 0.85=$ recovery of purines absorbed as purine derivatives in the urine; and $0.385=$ endogenous excretion of purine derivatives in the urine $(\mathrm{mmol})$ per unit of metabolic size (0.75 BW).

To estimate microbial protein production (MCP), purine bases (mmol/day) were used as a microbial indicator, whose quantification was performed according to the technique of Chen and Gomes (1992): MCP $(\mathrm{g} /$ day $)=\{(70 \times \mathrm{AP}) /(0.85 \times 0.116 \times 1000)\}$, assuming the value of 70 for the nitrogen content in the purines $(\mathrm{mg} / \mathrm{mmol}) ; 0.83$ for intestinal digestibility of microbial purines and 0.116 for the $\mathrm{N}_{\text {PURINE }}: \mathrm{N}_{\text {TOTAL }}$ ratio in bacteria.

The microbial crude protein synthesis efficiency was calculated as follows: microbial crude protein synthesis efficiency $=\{(0.629$ $x$ AP) $x$ 6.25)/TDN intake\}, where: $A P=$ absorbed purines (mmol/day); TDNI - total digestible nutrients intake; 0.629 represents the absorbed purine without considering the contribution of the endogenous fraction.

At the beginning and at the end (21 th) of each experimental period, after a 16hour fast of solids, the body weight of animals was evaluate, we used a mechanical scale (mechanical scale, Valfran, Votuporanga, São Paulo, Brazil). Moreover, measurements were made of the thoracic perimeter, withers and croup height and body length. The measurements were made according to the 
methodology of Hoffman (1997), with the animals in a forced station, that is, front and rear members perpendicular on a flat floor, forming a rectangular parallelogram. Feed efficiency was calculated by dividing weight gain (kg/day) with DM intake (kg/day).

On the 19th day of each experimental period, heifers were visually observed by trained people to evaluate their feeding behavior. Each animal was observed at 5-min intervals, for $24 \mathrm{~h}$, to determine the times spent on the feeding, ruminating, and idle activities. On the following day, the number of rumination chews was counted, and the time spent ruminating each cud was obtained per animal, using a digital timer.

To evaluate the kinetics of ruminal degradation of DM, OM and NDF of the different proportions $(0,33,67$ and 100\%) of forage sorghum silages and biomass sorghum silage, two adult and cannulated crossbred steers were used, mean BW of $510 \pm 36 \mathrm{~kg}$. The animals were adapted for 14 days to the diet containing $4 \mathrm{~kg}$ of concentrate (25\% CP and $65 \%$ TDN), divided into two meals, morning and afternoon, in addition to the provision of roughage based on sorghum silage $(50 \%$ FS silage and 50\% BRS 716 silage). The in situ degradability technique was used, using synthetic fiber bags of the non-woven type (weight 100), with porosity of approximately $50 \mu \mathrm{m}$, according to Casali et al. (2009), with quantity of samples following a ratio of 20 $\mathrm{mg} \mathrm{DM/cm}$ of the bag's surface area (Nocek, 1988).

The samples were deposited in the ventral sac region of the rumen for $0,3,6,12$, $24,48,72,96,120$ and 144 hours, with the end of the nylon thread tied to the cannula. The bags are placed in reverse order, starting with 144 hours. The samples referring to time 0 hours were washed in cold water along with the other samples. Subsequently, the samples were placed in greenhouses at $55^{\circ} \mathrm{C}$ for 72 hours and afterwards, cooled in a desiccator and weighed. The remaining residues in the non-woven bags, collected in the rumen, were analyzed for the contents of DM, OM and NDF. The percentage of degradation was calculated by the proportion of feed remaining in the bags after ruminal incubation.

The data obtained were adjusted for a non-linear regression by the Gauss-Newton method, using the SAS software (SAS Inst. Inc., Cary, NC, USA), according to the equation proposed by (Ørskov \& McDonald, 1979): $Y=a+$ $b\left(1-e^{\wedge}-c t\right)$, where: $Y=$ accumulated degradation of the analyzed nutritional component, after time $\mathrm{t}$; $\mathrm{a}$ = intercept of degradation curve when $\mathrm{t}=0$, which corresponds to the water-soluble fraction of the analyzed nutritional component; b - potential for degradation of the waterinsoluble fraction of the analyzed nutritional component; $a+b$ - potential degradation of the nutritional component analyzed when time is not a limiting factor; $c$ - degradation rate by fermentative action of $b ; t=$ incubation time. After calculated, the coefficients $a, b$ and $c$ were applied to the equation proposed by Ørskov and Mcdonald (1979): $E D=a+(b \times c / c$ $+k$ ), where: ED -effective ruminal degradation of the analyzed nutritional component; $\mathrm{k}$ passage rate of the feed. Rumen particle passage rates estimated at 2,5 and $8 \% / h$ were assumed, as suggested by the Agricultural and Food Research Council [AFRC] (1993).

The NDF degradability was estimated using the model: $R t=B \times e^{\wedge}-c t+I$, where, $\mathrm{R}=$ fraction degraded at time " $\mathrm{t}$ "; $\mathrm{B}=$ potentially degradable insoluble fraction and $\mathrm{I}=$ indigestible fraction. After adjusting the 
NDF degradation equation, fractions will be standardized, as proposed by Waldo, Smith, $\&$ Cox (1972), using the equations: $B p=B /$ $(B+I) \times 100 ; I p=I /(B+I) \times 100$, where: $\mathrm{Bp}=$ potentially standardized degradable fraction

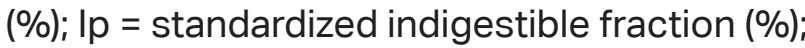
$\mathrm{B}=$ potentially degradable insoluble fraction and $\mathrm{I}=$ indigestible fraction. In the calculation of the effective NDF degradability, the model was used: $E D=B p \times c /(c+k)$, where $B p$ is the standardized potentially degradable fraction (\%).The disappearance value found at time zero ("a") was used to estimate the colonization time (CT) for DM and NDF, according to Goes et al. (2017), where the parameters "a", "b", and "c" were evaluated by the Gaus-Newton algorithm: $C T=\left[-\ln \left(a^{\prime}-a-b\right) / c\right]$.

Data were analyzed using the PROC MIXED of SAS 9.0 (Statistical Analysis System [SAS Institute], 2008). The UNIVARIATE procedure was used to detect outliers or influential values and to examine the normality of the residues. Nutrient intake, digestibility, nitrogen balance, behavioral variables, performance and body measurements were analyzed according to the following model:

$$
Y i j k=\mu+A k+B S S i+P j+I B W+e i j k,
$$

with $a_{1: k} \approx N\left(0 ; \sigma_{a}^{2}\right)$ and $e_{i j k} \approx N\left(0 ; \sigma_{e}^{2}\right)$; where: $Y$ ijk = observation on animal k, given treatment $\mathrm{i}$, at period $\mathrm{j} ; \mu=$ constant associated with all observations; $A \mathrm{k}=$ random effect of animal ( $k=1$ to 8$) ; B S S i$ = fixed effect of the $i$ th BRS 716 silage level $(i=1$ to 4$) ; P j=$ fixed effect of period ( $\mathrm{j}=1$ to 4 ); IBW = Initial body weight as covariate; e ijk = random error associated with each observation; N = Gaussian distribution; $\sigma_{a}^{2}=$ variance associated to heifers; $\sigma_{e}{ }^{2}=$ residual variance.

The DM, OM and NDF ruminal degradability assay was conducted in a randomized block design in subdivided plots, with 4 treatments (plots) and 10 incubation times (subplots). The variation in each animal was the blocking factor. Ruminal degradability variables were analyzed as repeated measures using the PROC MIXED, according to the following model:

$$
\begin{gathered}
Y i j k l m=\mu+B S S i+P j+B k+a l: k+\omega i j k l+T m+ \\
T \times B S S m i+e i j k l m,
\end{gathered}
$$

with a l:k $\approx N\left(0 ; \sigma_{a}^{2}\right), \omega i j k l \approx N\left(0 ; \sigma_{\omega}^{2}\right)$, and $e_{i j k l m}$ $\approx M V N(0 ; R)$; where $Y_{i j k l m}$ is the observation on animal $\mathrm{l}$, given treatment $\mathrm{i}$, at period $\mathrm{j}$, in block $k$, and time $m ; B_{k}=$ fixed effect of block ( $k=1$ to 4); $\omega \mathrm{ijkl}=$ residual error associated with heifers within experimental period; $T_{m}=$ fixed effect of sampling time ( $m=1$ to 10$) ; T \times S S B m i=$ fixed effect of biomass sorghum silage level by time interaction; $\sigma_{\omega}{ }^{2}=$ variance associated with experimental units (heifers within period); $\mathrm{MVN}=$ multivariate normal distribution; $\mathrm{R}=$ the variance-covariance matrix of residuals due to the repeated measurements. The following $\mu$, BSS $i, P j$ and a l:k were previously described. Variance covariance matrices were evaluated [CSH, AR(1), ARH(1), TOEP, TOEPH, UN, FA(1), and ANTE(1)] and chosen according to the Bayesian method. The biomass sorghum silage effects were decomposed into orthogonal contrasts to evaluate linear and quadratic effects. Significance level was set at $p \leq 0.05$.

\section{Results and Discussion}

The fraction "b", potentially degradable, of DM showed a linear linear effect of $0.05 \%$ for each $1 \%$ replacement of FS silage with BRS 716 silage. The other parameters of DM ruminal degradability, OM and NDF were similar ( $\mathrm{P}$ 0.05; Table 3). 
Table 3

Ruminal degradability of dry matter, organic matter and fibrous fraction (NDF) of forage sorghum silage and biomass sorghum silage and respective combinations

\begin{tabular}{|c|c|c|c|c|c|c|c|}
\hline \multirow{2}{*}{ Item (\% DM) } & \multicolumn{4}{|c|}{ Treatment ${ }^{\mathrm{a}}$} & \multirow{2}{*}{ SEM $^{b}$} & \multicolumn{2}{|c|}{ P-value $^{c}$} \\
\hline & 0 & 33 & 67 & 100 & & L & Q \\
\hline \multicolumn{8}{|c|}{ Dry matter, \% } \\
\hline Fraction "a" & 17.82 & 17.68 & 15.54 & 17.97 & 1.30 & 0.77 & 0.34 \\
\hline Fraction "b"1 & 49.18 & 50.93 & 51.04 & 55.21 & 1.75 & 0.03 & 0.50 \\
\hline Degradability rate "c", \%/h & 2.00 & 2.00 & 2.00 & 2.00 & $<0.01$ & 0.70 & 0.39 \\
\hline Potential Degradability & 67.00 & 68.61 & 66.58 & 73.18 & 2.07 & 0.10 & 0.25 \\
\hline Colonization time, $\mathrm{h}$ & 4.73 & 5.30 & 3.75 & 4.93 & 0.54 & 0.70 & 0.58 \\
\hline Undegradable fraction & 33.00 & 31.39 & 33.42 & 26.82 & 2.07 & 0.10 & 0.25 \\
\hline Effective Degradability - k=2\% & 43.11 & 41.51 & 42.34 & 44.27 & 0.99 & 0.35 & 0.10 \\
\hline Effective Degradability - $\mathrm{k}=5 \%$ & 32.49 & 31.08 & 31.20 & 32.86 & 1.01 & 0.78 & 0.15 \\
\hline Effective Degradability - k=8\% & 28.16 & 27.01 & 26.60 & 28.38 & 1.06 & 0.96 & 0.19 \\
\hline \multicolumn{8}{|c|}{ Organic matter, \% } \\
\hline Fraction "a" & 12.69 & 13.40 & 11.10 & 10.98 & 1.25 & 0.21 & 0.74 \\
\hline Fraction "b" & 55.56 & 55.43 & 54.82 & 59.15 & 1.94 & 0.26 & 0.27 \\
\hline Degradability rate "c", \%/h & 2.00 & 2.00 & 2.00 & 2.00 & $<0.01$ & 0.84 & 0.64 \\
\hline Potential Degradability & 68.24 & 68.82 & 65.93 & 70.14 & 2.36 & 0.80 & 0.45 \\
\hline Colonization time, $\mathrm{h}$ & 3.32 & 3.73 & 2.57 & 2.80 & 0.49 & 0.23 & 0.85 \\
\hline Undegradable fraction & 31.76 & 31.18 & 34.07 & 29.86 & 2.36 & 0.80 & 0.45 \\
\hline Effective Degradability - k=2\% & 39.52 & 39.03 & 39.49 & 39.16 & 0.89 & 0.88 & 0.93 \\
\hline Effective Degradability - k=5\% & 27.91 & 27.75 & 27.59 & 26.97 & 0.90 & 0.47 & 0.80 \\
\hline Effective Degradability - k=8\% & 23.32 & 23.38 & 22.72 & 22.16 & 0.95 & 0.35 & 0.75 \\
\hline \multicolumn{8}{|c|}{ Neutral detergent fiber, \% } \\
\hline Fraction "Bp" & 64.70 & 69.20 & 66.22 & 70.97 & 2.50 & 0.19 & 0.96 \\
\hline Degradability rate "c" \%/h & 2.00 & 2.00 & 2.00 & 2.00 & $<0.01$ & 0.58 & 0.67 \\
\hline Colonization time, $\mathrm{h}$ & 15.91 & 18.50 & 14.33 & 17.32 & 1.62 & 0.99 & 0.90 \\
\hline Undegradable fraction & 35.30 & 30.80 & 33.78 & 29.03 & 2.50 & 0.19 & 0.96 \\
\hline Effective Degradability - k=2\% & 38.26 & 32.94 & 40.01 & 32.06 & 3.19 & 0.44 & 0.69 \\
\hline Effective Degradability - $k=5 \%$ & 18.17 & 17.23 & 20.64 & 18.37 & 1.80 & 0.42 & 0.55 \\
\hline Effective Degradability - $\mathrm{k}=8 \%$ & 35.23 & 30.73 & 33.72 & 28.96 & 2.50 & 0.19 & 0.96 \\
\hline
\end{tabular}

a Control diet (0) with forage sorghum silage and biomass sorghum silage replacing forage sorghum silage at 33, 67 and $100 \%$.

${ }^{\mathrm{b}}$ Probabilities for linear (L) and quadratic (Q) effects;

c Standard error of the mean;

${ }^{1}$ Regression equation: $\hat{Y}=48.86+0.05^{*} X, R^{2}=0.84$ where $\hat{Y}$ is the predicted value for each variable and $X$ is the inclusion level of biomass sorghum silage. $\mathrm{R}^{2}$ is the coefficient of determination. ${ }^{*}$ significant by the $t$ test $(\alpha<0.05)$. $\mathrm{k}$ - Passage rate $2 \%, 5 \%$ and $8 \%$ (AFRC, 1993). 
There was no difference in DM intake (DMl; $p=0.45$ ), mean of $10.94 \mathrm{~kg} /$ day. The iNDF and EE intake (kg/day and \% BW) decreased linearly $(p<0.01)$ with the increased of BRS 716 silage. There were no changes in the intake of the other fractions ( $p>0.05$; Table 4).

Table 4

Nutrient intake and apparent total-tract digestibility in $3 / 4$ Holstein $\times 1 / 4$ Zebu heifers fed diets containing forage sorghum silage in replacement with biomass sorghum silage

\begin{tabular}{|c|c|c|c|c|c|c|c|}
\hline \multirow{2}{*}{ Item } & \multicolumn{4}{|c|}{ Treatment $^{a}$} & \multirow{2}{*}{ SEM $^{b}$} & \multicolumn{2}{|c|}{ P-value } \\
\hline & 0 & 33 & 67 & 100 & & $\mathrm{~L}$ & Q \\
\hline \multicolumn{8}{|c|}{ Intake, kg/d } \\
\hline Dry matter & 10.90 & 11.19 & 11.03 & 10.63 & 0.80 & 0.45 & 0.23 \\
\hline Crude protein & 0.87 & 0.85 & 0.80 & 0.82 & 0.03 & 0.14 & 0.33 \\
\hline Ether extract ${ }^{1}$ & 0.30 & 0.30 & 0.28 & 0.23 & 0.03 & $<0.01$ & 0.04 \\
\hline NDFap & 4.73 & 4.82 & 4.73 & 3.94 & 0.46 & 0.09 & 0.16 \\
\hline iNDF $^{2}$ & 1.82 & 1.68 & 1.47 & 1.07 & 0.06 & $<0.01$ & 0.05 \\
\hline Non-fibrous carbohydrates & 3.50 & 3.52 & 3.43 & 3.23 & 0.25 & 0.08 & 0.31 \\
\hline Total digestible nutrients & 6.16 & 6.43 & 6.61 & 6.24 & 0.58 & 0.76 & 0.30 \\
\hline Metabolizable energy, Mcal/d & 22.53 & 23.59 & 24.49 & 23.01 & 2.27 & 0.68 & 0.32 \\
\hline Net energy, Mcal/d & 13.78 & 14.40 & 14.87 & 14.01 & 0.63 & 0.68 & 0.25 \\
\hline \multicolumn{8}{|c|}{ Intake, \% BW } \\
\hline Dry matter & 3.39 & 3.47 & 3.36 & 3.25 & 0.16 & 0.41 & 0.49 \\
\hline Crude protein & 0.27 & 0.26 & 0.25 & 0.25 & 0.01 & 0.85 & 0.34 \\
\hline Ether extract ${ }^{3}$ & 0.09 & 0.09 & 0.08 & 0.07 & 0.01 & $<0.01$ & 0.13 \\
\hline NDFap & 1.48 & 1.50 & 1.46 & 1.16 & 0.12 & 0.08 & 0.18 \\
\hline iNDF ${ }^{4}$ & 0.57 & 0.52 & 0.45 & 0.31 & 0.02 & $<0.01$ & 0.10 \\
\hline Non-fibrous carbohydrates & 1.09 & 1.09 & 1.05 & 0.98 & 0.05 & 0.09 & 0.42 \\
\hline Total digestible nutrients & 1.93 & 2.00 & 2.01 & 1.86 & 0.13 & 0.75 & 0.38 \\
\hline \multicolumn{8}{|c|}{ Apparent total tract digestibility, \% } \\
\hline Dry matter ${ }^{5}$ & 63.00 & 65.58 & 69.66 & 77.99 & 2.23 & $<0.01$ & 0.21 \\
\hline Crude protein ${ }^{6}$ & 50.45 & 50.98 & 54.71 & 64.58 & 2.87 & $<0.01$ & 0.07 \\
\hline Ether extract ${ }^{7}$ & 74.76 & 78.72 & 79.68 & 86.32 & 2.23 & $<0.01$ & 0.53 \\
\hline NDFap ${ }^{8}$ & 45.84 & 52.50 & 56.17 & 61.88 & 2.47 & $<0.01$ & 0.81 \\
\hline Non-fibrous carbohydrates & 85.93 & 83.74 & 87.22 & 89.23 & 2.34 & 0.22 & 0.38 \\
\hline Total digestible nutrients & 56.36 & 57.43 & 59.67 & 57.55 & 2.10 & 0.51 & 0.42 \\
\hline \multicolumn{8}{|c|}{ 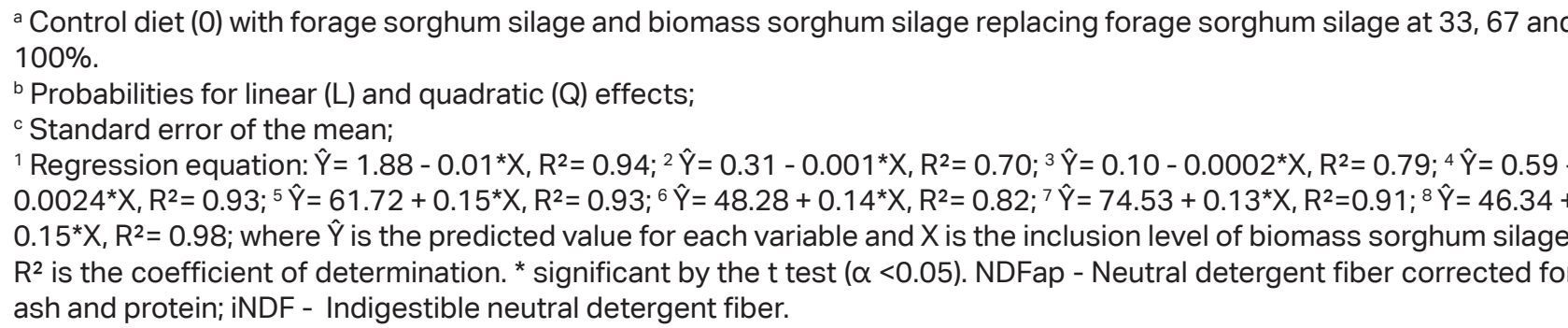 } \\
\hline
\end{tabular}


The digestibility of DM, CP, EE and NDFap increased linearly with the inclusion of BRS 716 silage to replace FS silage $(P<0.05)$. The digestibility of non-fibrous carbohydrates $(p=$ 0.22 ) and the total digestible nutrients ( $p=0.51)$ did not have an effect of substituting FS silage with BRS 716 silage.
There was no difference between treatments on nitrogen balance $(p=0.49)$, plasma urea nitrogen $(p=0.69)$ and urine urea nitrogen $(p=0.69)$, with mean of $59.7 \mathrm{~g} / \mathrm{day}, 16.32 \mathrm{mg} / \mathrm{dL}$ and $1.63 \mathrm{mg} / \mathrm{dL}$, respectively (Table 5). The means for $\mathrm{N}$-feces (g/day and \% $\mathrm{N}$-ingested) adjusted to the quadratic regression model with maximum point of $56.16 \%$ and $49,16 \%$, respectively.

\section{Table 5}

Nitrogen balance in $3 / 4$ Holstein $\times 1 / 4$ Zebu heifers fed diets containing forage sorghum silage in replacement with biomass sorghum silage

\begin{tabular}{|c|c|c|c|c|c|c|c|}
\hline \multirow{2}{*}{ Item } & \multicolumn{4}{|c|}{ Treatment $^{\mathrm{a}}$} & \multirow{2}{*}{ SEM $^{b}$} & \multicolumn{2}{|c|}{ P-value ${ }^{c}$} \\
\hline & 0 & 33 & 67 & 100 & & $\mathrm{~L}$ & $Q$ \\
\hline \multicolumn{8}{|c|}{ Balance of nitrogen compounds } \\
\hline$N$ - ingested, g/d ${ }^{1}$ & 139.24 & 136.00 & 127.27 & 131.20 & 3.80 & 0.11 & 0.21 \\
\hline$N$ - feces, g/d ${ }^{2}$ & 16.86 & 17.39 & 17.50 & 16.35 & 0.34 & 0.37 & 0.02 \\
\hline$N$ - urine, g/d & 66.13 & 65.05 & 43.95 & 51.67 & 9.30 & 0.13 & 0.64 \\
\hline Nitrogen balance, g/d & 56.24 & 53.57 & 65.81 & 63.18 & 8.91 & 0.41 & 0.22 \\
\hline $\mathrm{N}-$ feces, $_{0} \mathrm{~N}$ ing $^{3}$ & 12.95 & 13.62 & 14.48 & 12.46 & 1.00 & $<0.01$ & 0.01 \\
\hline $\mathrm{N}$ - urine, \% N ing. & 51.33 & 49.69 & 36.23 & 39.38 & 6.42 & 0.29 & 0.40 \\
\hline Nitrogen balance, \% N ing. & 35.71 & 36.68 & 44.28 & 48.15 & 6.15 & 0.49 & 0.32 \\
\hline Plasma urea nitrogen, $\mathrm{mg} / \mathrm{dL}$ & 15.42 & 17.39 & 16.22 & 16.23 & 0.68 & 0.69 & 0.17 \\
\hline Urine urea nitrogen, mg/dL & 1.54 & 1.74 & 1.62 & 1.62 & 0.06 & 0.69 & 0.16 \\
\hline \multicolumn{8}{|c|}{ Microbial production } \\
\hline Total Purines, mmol/d & 159.71 & 182.21 & 183.70 & 154.30 & 10.34 & 0.75 & 0.13 \\
\hline Absorbed purine, g/d & 153.29 & 179.69 & 181.16 & 146.57 & 12.20 & 0.73 & 0.13 \\
\hline Microbial crude protein, g/d & 696.57 & 816.50 & 823.17 & 666.02 & 55.48 & 0.73 & 0.13 \\
\hline Microbial efficiency, g MCP/kg TDN & 122.02 & 134.34 & 133.15 & 121.40 & 13.33 & 0.95 & 0.37 \\
\hline
\end{tabular}

a Control diet (0) with forage sorghum silage and biomass sorghum silage replacing forage sorghum silage at 33, 67 and $100 \%$.

b Probabilities for linear (L) and quadratic (Q) effects;

c Standard error of the mean;

${ }^{1}$ Regression equation: $\hat{Y}=140.15-0.26^{*} X+0.002^{*} X^{2}, R^{2}=0.80 ;{ }^{2} \hat{Y}=16.81+0.03^{*} X-0.0003^{*} X^{2}, R^{2}=0.95 ;{ }^{3} \hat{Y}=12.79$ $+0.06^{*} X-0.0006^{*} X^{2}, R^{2}=0.80$; where $\hat{Y}$ is the predicted value for each variable and $X$ is the inclusion level of biomass sorghum silage. $\mathrm{R}^{2}$ is the coefficient of determination. ${ }^{*}$ significant by the t test $(\alpha<0.05) ; \mathrm{N}$ ing $-\mathrm{N}$ - ingested.

The replacement of FS silage with BRS 716 silage in diets for dairy heifers did not change the concentration of total purines $(p=0.75)$, absorbed purine $(p=0.73)$, microbial crude protein $(p=0.73)$ and microbial efficiency $(p=0.95)$.
The replacement of FS silage with BRS 716 silage changed the duration of the periods in rumination $(p=0.02)$ and the rumination efficiency in number of bolus/d ( $p=0.03$ ) (Table 6). Both variables showed quadratic regression behavior. The maximum points were verified with $41.11 \%$ and $44.90 \%$ inclusion of BRS 716 silage, respectively. 
Table 6

Ingestive behavior in $3 / 4$ Holstein $x$ Zebu heifers fed diets containing forage sorghum silage in replacement with biomass sorghum silage

\begin{tabular}{|c|c|c|c|c|c|c|c|}
\hline \multirow{2}{*}{ Item } & \multicolumn{4}{|c|}{ Treatment $^{a}$} & \multirow{2}{*}{$\mathrm{SEM}^{\mathrm{b}}$} & \multicolumn{2}{|c|}{ P-value } \\
\hline & 0 & 33 & 67 & 100 & & $\mathrm{~L}$ & $Q$ \\
\hline \multicolumn{8}{|l|}{ Feeding } \\
\hline $\min / d$ & 334.37 & 344.38 & 340.63 & 312.50 & 14.47 & 0.22 & 0.14 \\
\hline $\mathrm{min} / \mathrm{kg} \mathrm{DM}$ & 30.68 & 30.77 & 30.88 & 29.39 & 3.52 & 0.45 & 0.23 \\
\hline min/kg NDFap ${ }^{1}$ & 70.72 & 71.41 & 71.96 & 79.28 & 4.79 & 0.08 & 0.16 \\
\hline \multicolumn{8}{|l|}{ Rumination } \\
\hline $\mathrm{min} / \mathrm{d}$ & 544.37 & 556.88 & 574.37 & 546.25 & 19.03 & 0.77 & 0.25 \\
\hline $\mathrm{min} / \mathrm{kg} \mathrm{DM}^{2}$ & 51.37 & 51.73 & 55.49 & 53.18 & 4.82 & 0.52 & 0.68 \\
\hline $\mathrm{min} / \mathrm{kg}$ NDFap ${ }^{1}$ & 120.42 & 122.53 & 130.53 & 165.17 & 19.12 & 0.06 & 0.32 \\
\hline \multicolumn{8}{|l|}{ Idle } \\
\hline $\min / d$ & 561.25 & 538.75 & 525.00 & 581.25 & 25.81 & 0.63 & 0.08 \\
\hline \multicolumn{8}{|l|}{ Chewing } \\
\hline number /bolus & 61.47 & 58.88 & 61.53 & 65.65 & 3.28 & 0.07 & 0.08 \\
\hline Total, h/d & 14.65 & 15.02 & 15.25 & 14.31 & 0.43 & 0.63 & 0.08 \\
\hline $\mathrm{min} /$ bolus & 49.35 & 48.43 & 48.40 & 49.17 & 1.32 & 0.80 & 0.09 \\
\hline $\mathrm{min} / \mathrm{kg} \mathrm{DM}{ }^{2}$ & 82.99 & 83.74 & 88.13 & 84.19 & 7.69 & 0.70 & 0.61 \\
\hline $\mathrm{min} / \mathrm{kg}$ NDFap ${ }^{1}$ & 195.41 & 198.36 & 206.63 & 261.60 & 30.45 & 0.07 & 0.30 \\
\hline \multicolumn{8}{|c|}{ Number of periods (n/d) } \\
\hline Feeding & 4.88 & 4.63 & 5.13 & 4.50 & 0.48 & 0.77 & 0.70 \\
\hline Rumination & 12.13 & 11.63 & 12.38 & 13.13 & 0.55 & 0.13 & 0.26 \\
\hline Idle & 15.88 & 15.38 & 16.75 & 17.25 & 0.67 & 0.08 & 0.47 \\
\hline \multicolumn{8}{|c|}{ Duration of periods (min) } \\
\hline Feeding & 71.39 & 78.89 & 71.45 & 79.64 & 8.79 & 0.64 & 0.97 \\
\hline Rumination ${ }^{4}$ & 45.31 & 48.30 & 46.99 & 41.91 & 1.92 & 0.13 & 0.02 \\
\hline Idle & 36.09 & 35.45 & 31.74 & 34.29 & 2.46 & 0.42 & 0.52 \\
\hline \multicolumn{8}{|l|}{ Feed efficiency } \\
\hline $\mathrm{g} \mathrm{DM} / \mathrm{h}$ & 1962.28 & 1957.92 & 1982.67 & 2108.14 & 171.46 & 0.29 & 0.51 \\
\hline g NDFap/h & 846.65 & 846.41 & 841.66 & 784.80 & 87.81 & 0.45 & 0.62 \\
\hline \multicolumn{8}{|c|}{ Rumination efficiency } \\
\hline Bolus/d ${ }^{5}$ & 659.57 & 718.00 & 714.33 & 621.88 & 43.08 & 0.43 & 0.03 \\
\hline g DM/h & 1205.92 & 1212.25 & 1168.43 & 1171.63 & 89.51 & 0.55 & 0.98 \\
\hline g NDFap/h & 516.94 & 523.86 & 497.41 & 435.06 & 47.07 & 0.08 & 0.30 \\
\hline
\end{tabular}

a Control diet (0) with forage sorghum silage and biomass sorghum silage replacing forage sorghum silage at 33, 67 and $100 \%$.

b Probabilities for linear (L) and quadratic (Q) effects;

c Standard error of the mean;

${ }^{4}$ Regression equation: $\hat{Y}=45.33+0.15^{*} X-0.002^{*} X 2, R^{2}=0.99 ;{ }^{5} \hat{Y}=658.18+3.06^{*} X-0.03^{*} X 2, R^{2}=0.99$; where $\hat{Y}$ is the predicted value for each variable and $X$ is the inclusion level of biomass sorghum silage. $R^{2}$ is the coefficient of determination. * significant by the $t$ test $(\alpha<0.05)$. NDFap - Neutral detergent fiber corrected for ash and protein; DM - Dry matter. 
The replacement of FS silage with BRS 716 silage did not influence the performance ( $p>0.05$ ) of the $3 / 4$ Holstein $\times 1 / 4$ Zebu heifers. The means values for final BW $(\mathrm{kg})$, average daily gain and feed efficiency were $328.73 \mathrm{~kg}$, $1.29 \mathrm{~kg} /$ day and $0.11 \mathrm{~kg} / \mathrm{kg} \mathrm{DMl}$, respectively
(Table 7). There was a $35.84 \%$ reduction in the feed cost of heifers with the replacement of FS silage with BRS 716 silage. There was no difference between treatment on body measurements $(p>0.05)$.

\section{Table 7}

Productive performance in $3 / 4$ Holstein $\times 1 / 4$ Zebu heifers fed diets containing forage sorghum silage in replacement with biomass sorghum silage

\begin{tabular}{|c|c|c|c|c|c|c|c|}
\hline \multirow{2}{*}{ Item } & \multicolumn{4}{|c|}{ Treatment $^{\mathrm{a}}$} & \multirow{2}{*}{ SEM $^{b}$} & \multicolumn{2}{|c|}{ P-value ${ }^{c}$} \\
\hline & 0 & 33 & 67 & 100 & & L & Quad \\
\hline \multicolumn{8}{|c|}{ Performance } \\
\hline Final body weight, kg & 325.75 & 327.25 & 331.00 & 330.94 & 27.97 & 0.75 & 0.95 \\
\hline Average daily gain, kg/d & 1.26 & 1.30 & 1.31 & 1.32 & 0.20 & 0.82 & 0.93 \\
\hline Feed efficiency, kg DM/kg DMI & 0.13 & 0.10 & 0.14 & 0.10 & 0.01 & 0.36 & 0.96 \\
\hline Feed cost, \$/day & 1.28 & 1.21 & 1.08 & 0.94 & 0.02 & - & - \\
\hline \multicolumn{8}{|c|}{ Body biometrics, $\mathrm{cm}$} \\
\hline Final thoracic perimeter & 163.75 & 164.44 & 164.62 & 163.87 & 4.75 & 0.95 & 0.71 \\
\hline Thoracic perimeter difference $^{1}$ & 0.15 & 0.23 & 0.19 & 0.17 & 0.04 & 0.91 & 0.16 \\
\hline Final height withers & 131.56 & 131.75 & 131.75 & 131.37 & 2.89 & 0.83 & 0.63 \\
\hline Height withers difference ${ }^{2}$ & 0.04 & 0.06 & 0.05 & 0.04 & 0.01 & 0.62 & 0.19 \\
\hline Height withers gain, ADG/ HW & 13.12 & 17.84 & 16.34 & 20.45 & 7.06 & 0.52 & 0.96 \\
\hline Final croup height & 137.37 & 137.31 & 137.31 & 137.69 & 2.49 & 0.65 & 0.64 \\
\hline Croup height difference ${ }^{3}$ & 0.04 & 0.05 & 0.04 & 0.06 & 0.01 & 0.25 & 1.00 \\
\hline Croup height gain, ADG/CH & 27.87 & 17.76 & 32.04 & 13.44 & 8.44 & 0.45 & 0.62 \\
\hline Final Body Length & 137.25 & 137.00 & 136.63 & 138.25 & 3.46 & 0.65 & 0.47 \\
\hline Body Length difference ${ }^{4}$ & 0.11 & 0.12 & 0.08 & 0.13 & 0.03 & 0.91 & 0.40 \\
\hline Body Length gain, ADG/BL & 9.07 & 5.01 & 5.79 & 12.53 & 2.07 & 0.24 & 0.07 \\
\hline \multicolumn{8}{|c|}{$\begin{array}{l}\text { a Control diet (0) with forage sorghum silage and biomass sorghum silage replacing forage sorghum silage at 33, } 67 \text { ano } \\
100 \% \text {. } \\
\text { b Probabilities for linear (L) and quadratic (Q) effects; } \\
\text { c Standard error of the mean; } \\
1 \text { Difference between final and initial thoracic perimeter; }{ }^{2} \text { Difference between final and initial height withers (HW) } \\
{ }^{3} \text { Difference between final and initial croup height }(\mathrm{CH}) ;{ }^{4} \text { Difference between final and initial body length (BL); ADG } \\
\text { Average daily weight gain. }\end{array}$} \\
\hline
\end{tabular}


The replacement of forage sorghum with biomass sorghum for silage production is mainly justified by the high productivity of biomass sorghum, resulting in lower production cost silage. According to Castro et al. (2015), the green mass yield of biomass sorghum BRS 716 (61.77 t/ ha) is $40.16 \%$ higher than that of forage sorghum (i.e., Volumax; $36.96 \mathrm{t} / \mathrm{ha}$ ), traditionally grown in Brazil for silage production. However, due to the higher fiber content of biomass sorghum compared to forage sorghum, there may be changes in DMl and animal performance. However, in this research, the DMI of the heifers was not changed, mean of $10.93 \mathrm{~kg} /$ day, which can be justified by the similarity in the potential and effective degradability of DM, $\mathrm{OM}$ and NDF of silages and their respective associations in experimental diets. Despite the greater proportion of the fibrous component (NDFap) in sorghum biomass in relation to forage sorghum, the iNDF content is lower in sorghum biomass, which explains the results of ruminal degradability and consequently of DMI. According to Detmann, Gionbelli and Huhtanen (2014), in diets with high iNDF content, found a negative correlation with DMI.

The highest dry matter digestibility with increasing levels of inclusion of BRS 716 silage is justified by lower lignin content, iNDF and ADF in the BRS 716 silage compared with FS silage. Moreover, despite the higher content of NDFap in BRS 716 silage, the linkages between lignin and can't be modified hemecelullose the extent of digestion of cellulose and hemecelullose by rumen microorganisms (Jung, 1989; Silva et al., 2018; Ramos et al., 2021). In view of the potential and effective degradability of DM and NDF was similar and insoluble fraction of the DM linearly increased with increasing levels of BRS 716 silage.
The greater amount of NDFap in the BRS 716 silage associated with the lower digestibility of NDFap in the FS silage may justify the quadratic behavior of parameters of the rumination behavior. Rumination time is influenced by the NDF intake and the physical characteristics of the forage (Beauchemin, 2018; L. D. A. Borges et al., 2019). Therefore, the action of ruminating it's fundamental role in the use of carbohydrates present in the fibrous fraction of the diet (Pimentel et al., 2017).

The replacement of FS silage with BRS 716 silage did not change the DM intake, protein and energy, microbial crude protein and microbial efficiency. Demonstrating the potential of this forage for the supply of metabolizable protein to the host animal. According to Sniffen and Robinson (1987), feed intake is one of the main factors that affect microbial efficiency, which allows for an increase in both microbial protein synthesis and microorganisms that pass to the small intestine.

The nitrogen balance was positive and similar between diets with different proportions of FS silage and BRS 716 silage (mean of $+59.70 \mathrm{~g} /$ day), indicating that the metabolic response to protein intake was adequate, being able to avoid productive, reproductive and environmental effects due to the better use of this nutrient by heifers (Mohd et al., 2015; Williams et al., 2019), with the response of their growth. The behavior verified between treatments on nitrogen balance, microbial synthesis in the rumen, TDN intake and metabolizable energy by animals show the balance between protein and energy in experimental diets, a fact that may justify the similarity in the performance of heifers. It is noteworthy that although the average weight 
gain was considered high (mean of $1.3 \mathrm{~kg} / \mathrm{day}$ ), the animals grew in stature, with weight gain in muscle tissue (Mohd et al., 2015; Williams et al., 2019).

One of the main objectives of raising dairy heifers is to ensure that the growth phase is not long (over one year), as this period is financially unproductive and its duration has an effect on the total cost of raising (Boulton, Rushton, \& Wathes, 2017; Erickson et al., 2020). Therefore, the weight gain of the animals verified in this research can contribute to their correct development and, consequently, assist in reducing the age at first calving of females destined for milk yield, which in Brazil presents between 30 to 35 mo (Borges, Martins, Nunes, \& Ruas, 2015).

The results obtained in this research show the potential of using BRS 716 silage in diets of dairy heifers. This potential is justified by the animals' performance and lower feed cost compared to FS silage, due to the high productivity of biomass sorghum even in semiarid conditions. Thus, the use of BRS 716 silage for silage production in semiarid regions becomes an alternative to optimize the production of feed for ruminant animals. Contributing to minimize the great forage seasonality due to the adverse climatic conditions in these locations (Daniel, Bernardes, Jobim, Schmidt, \& Nussio, 2019; Queiroz et al., 2021; Ramos et al., 2021).

\section{Conclusion}

The replacement of forage sorghum silage with biomass sorghum silage BRS 716 in diet for $3 / 4$ Holstein $x 1 / 4$ Zebu heifers increases the dry matter digestibility and fibrous fraction. Without changing the dry matter intake and energy, maintaining the weight gain and body measurements of heifers. Therefore, biomass sorghum silage can replace up to $100 \%$ of forage sorghum silage.

\section{Acknowledgements}

The authors would like to thank the Fundação de Amparo à Pesquisa do Estado de Minas Gerais (FAPEMIG), Universidade Estadual de Montes Claros (Unimontes), Conselho Nacional de Desenvolvimento Científico e Tecnológico (CNPq), Instituto Nacional de Ciência e Tecnologia (INCT Ciência Animal), and Embrapa Milho e Sorgo, for their assistance with scholarships/ research. The authors would like to thank the undergraduate students for their contribution towards the accomplishment of the research. This study was financed in part by the Coordenação de Aperfeiçoamento de Pessoal de Nível Superior - Brasil (CAPES) - Finance Code 001.

\section{References}

Agricultural and Food Research Council (1993). Energy and protein requirements of ruminants. Walligford: CAB International.

Almeida, L. G. F. de, Parrella, R. A. da C., Simeone, M. L. F., Ribeiro, P. C. de O., Santos, A. S. dos, Costa, A. S. V.,... Schaffert, R. E. (2019). Composition and growth of sorghum biomass genotypes for ethanol production. Biomass and Bioenergy, 122(1), 343-348. doi: 10.1016/j. biombioe.2019.01.030

Beauchemin, K. A. (2018). Invited review: current perspectives on eating and rumination activity in dairy cows. Journal of Dairy Science, 101(1), 1-23. doi: 10.3168/jds.2017-13706 
Borges, A. M., Martins, T. M., Nunes, P. P., \& Ruas, J. R. M. (2015). Reproduction of crossbreeding dairy cows: potentiality and challenges. Revista Brasileira de Reprodução Animal, 39(1), 155-163.

Borges, L. D. A., Rocha, V. R., Jr., Monção, F. P., Soares, C., Silva, F. V., Rigueira, J. P. S.,... Rabelo, W. O. (2019). Nutritional and productive parameters of Holstein/Zebu cows fed diets containing cactus pear. Asian-Australasian Journal of Animal Sciences, 32(9), 1373-1380. doi: 10.5713/ ajas. 18.0584

Boulton, A. C., Rushton, J., \& Wathes, D. C. (2017). An empirical analysis of the cost of rearing dairy heifers from birth to first calving and the time taken to repay these costs. Animal, 11(8), 1372-1380. doi: 10. 1017/S1751731117000064

Casali, A. O., Detmann, E., Valadares, S. C., Fo., Pereira, J. C., Cunha, M., Detmann, K. S. C., \& Paulino, M. F. (2009). Estimação de teores de componentes fibrosos em alimentos para ruminantes em sacos de diferentes tecidos. Revista Brasileira de Zootecnia, 38(1), 130-138. doi: 10.1590/ S1516-35982009000100017

Castro, F. M. R., Bruzi, A. T., Nunes, J. A. R., Parrella, R. A. C., Lombardi, G. M. R., Albuquerque, C. J. B., \& Lopes, M. (2015). Agronomic and energetic potential of biomass sorghum genotypes. American Journal of Plant Sciences, 6(6), 18621873. doi: 10.4236/ajps.2015.611187

Chen, X. B., \& Gomes, M. J. (1992). Estimation of microbial protein supply to sheep and cattle based on urinary excretion of purine derivatives- an overview of technical details. Aberdeen, UK: International feed research unit. Rowell Research Institute.

Chizzotti, M. L., Valadares, S. C., Valadares, R. F. D., Fo., Chizzotti, F. H. M., \& Tedeschi,
L. O. (2008). Determination of creatinine excretion and evaluation of spot urine sampling in Holstein cattle. Livestock Science, 113(2), 218-225. doi: 10.1016/j. livsci.2007.03.013

Costa, N. M., Rocha, V. R., Jr., Caldeira, L. A., Monção, F. P., Rabelo, W. O., Silva, F. V.,... Carvalho, C.C.S.(2020).FeedingF1 Holstein $x$ Zebu cows with different roughages and pseudostem hay of banana trees does not influence milk yield and chemical composition of milk and cheese. Italian Journal of Animal Science, 20(1), 1-10. doi: 10.1080/1828051X.2020.1773327

Daniel, J. L. P., Bernardes, T. F., Jobim, C. C., Schmidt, P., \& Nussio, L. G. (2019). Production and utilization of silages in tropical areas with focus on Brazil. Grass and Forage Science, 74(2), 1-18. doi: $10.1111 / \mathrm{gfs} .12417$

Detmann, E., Gionbelli, M. P., \& Huhtanen, P. (2014). A meta-analytical evaluation of the regulation of voluntary intake in cattle fed tropical forage-based diets. Journal of Animal Science, 92(10), 4632-4641. doi: 10.2527/jas.2014-7717

Detmann, E., Souza, M. A., Valadares, S. C., Fo., Queiroz, A. C., Berchielli, T. T., Saliba, E. O. S.,... Azevedo, J. A. G. (2012). Methods for food analysis. Visconde do Rio Branco: Suprema.

Erickson, P. S., Anderson, J. L., Kalscheur, K. F., Lascano, G. J., Akins, M. S., \& Heinrichs, A. J. (2020). Symposium review: Strategies to improve the efficiency and profitability of heifer raising. Journal of Dairy Science, 103(6), 5700-5708. doi: 10.3168/jds.201917419

Food and Agriculture Organization [FAO; FAOSTAT] (2020). Crops and livestock products. https://www.fao.org/faostat/en/ \#data/QCL/visualize 
Goes, R. H. T. B., Patussi, R. A., Gandra, J. R., Branco, A. F., Cardoso, T. J. L., Oliveira, M. V. M.,... Souza, C. J. S. (2017). The crambe Crambe abyssinica Hochst byproducts, can be used as a source of non-degradable protein in the rumen? Bioscience Journal, 33(1), 113-120. doi: 10.14393/BJ-v33n1a2017-33105

Hoffman, P. C. (1997). Optimum body size of Holstein replacement heifers. Journal of Animal Science, 75(3), 836-845. doi: 10.2527/1997.753836x

Jung, H. G. (1989). Forage lignin and their effects on fiber digestibility. Agricultural Journal, 81(1), 33-38. doi: 10.2134/agronj $1989.00021962008100010006 x$

Mohd, N., Steeneveld, W., Mourits, M. C. M., \& Hogeveen, H. (2015). The optimal number of heifer calves to be reared as dairy replacements. Journal of Dairy Science, 98(2), 861-871. doi: 10.3168/jds.20148329

Monção, F. P., Costa, M. A. M. S., Rigueira, J. P. S., Moura, M. M. A., Rocha, V. R., Jr., Mesquita, V. G.,... Chamone, J. M. A. (2019a). Yield and nutritional value of BRS capiaçu grass at different regrowth ages. Semina: Ciências Agrárias, 41(5), 745-755. doi: 10.5433/1679-0359.2019v40n5p2045

Monção, F. P., Costa, M. A. M. S., Rigueira, J. P. S., Sales, E. C. J., Leal, D. B., Silva, M. F. P.,... Rocha, V. R., Jr. (2019b). Productivity and nutritional value of BRS capiaçu grass (Pennisetum purpureum) managed at four regrowth ages in a semiarid region. Tropical Animal Health and Production, 52(1), 235-241. doi: 10.1007/s11250019-02012-y

National Research Council (2001). Nutrient requirements of dairy cattle (7nd rev. ed.). Washington, DC: National Academies Press.
Nocek, J. E. (1988). In situ and other methods to estimate ruminal protein and energy digestibility: a review. Journal of Dairy Science, 71(8), 2051-2069. doi: 10.3168/ jds.S0022-0302(88)79781-7

Ørskov, E. R., \& Mcdonald, I. (1979). The estimation of degradability in the rumen form incubation measurement weighted according to rate of passage. Journal of Agricultural Science, 92(2), 499-508. doi: $10.1017 / S 0021859600063048$

Pimentel, P. R. S., Rocha, V. R., Jr., Melo, M. T. P., Ruas, J. R. M., Brant, L. M. S., Costa, N. M.,... Maranhão, C. M. A. (2017). Banana peel in the diet for F1 Holstein $x$ Zebu cows. Semina: Ciências Agrárias, 38(2), 969-980. doi: 10.5433/1679-0359.2017v38n2p969

Pino, F., \& Heinrichs, A. J. (2017). Sorghum forage in precision-fed dairy heifer diets. Journal of Dairy Science, 100(1), 224-235. doi: 10.3168/jds.2016-11551

Queiroz, F. E., Rocha, V. R., Jr., Monção, F. P., Rigueira, J. P. S., Parrella, R. A. C., Rufino, L. D. A.,... Cordeiro, M. W. S. (2021). Effect of row spacing and maturity at harvest on the fermentative profile, aerobic stability, and nutritional characteristics of biomass sorghum (BRS 716) silage in the semiarid region of Brazil. Revista Brasileira de Zootecnia, 50(1), e20200254. doi: $10.37496 / \mathrm{rbz} 5020200254$

Ramos, J. C. P., Rocha, V. R., Jr., Monção, F. P., Parrela, R. A. C., Caxito, A. M., Cordeiro, M. W. S.,... Pires, D. A. A. (2021). Effect of replacing forage sorghum silage with biomass sorghum silage in diets for $F 1$ Holstein $\times$ Zebu lactating cows. Tropical Animal Health and Production, 53(1), 1-12. doi: 10.1007/s11250-020-02503-3

Silva, F. A. S., Valadares, S. C., F., Detmann, E., Santos, S. A., Godoi, L. A., Silva, B. C.,... Rotta, P. P. (2018). Effect of different forage 
types and concentrate levels on energy conversion, enteric methane production, and animal performance of Holstein $\mathrm{x}$ Zebu heifers. Animal Production Science, 57(10), 2042-2050. doi: 10.1071/AN16093

Sniffen, C. J., Robinson, P. H. (1987). Protein and fiber digestion, passage, and utilization in lactating cows. Microbial growth and flow as influenced by dietary manipulations. Journal of Dairy Science, 70(2), 425-41. doi: 10.3168/jds.s0022-0302(87)80027-9

Souza, I. D. A. S., Rocha, V. R., Jr., Monção, F. P., Parrella, R. A. C., Cordeiro, M. W. S., Carvalho, C. C. S.,... Delvaux, N. A., Jr. (2021). Yield and nutritional value of biomass sorghum (BRS 716) managed in different row spacing and maturity at harvest in the semiarid region of Brazil. Semina: Ciências Agrárias, 42(6), 34633484. doi: 10.5433/1679-0359.2021v42n $6 \mathrm{p} 3463$

Statistical Analysis System (2008). SAS/ STAT 9.0 users guide. inc. Cary, NC: SAS Institute.
Verbic, J., Chen, X. B., \& Macleod, N. A. (1990). Excretion of purine derivatives by ruminants. Effect of microbial nucleic acid infusionon purine derivative excretion by steers. The Journal of Agricultural Science, 114(3), 243-248. doi: 10.1017/ S0021859600072610

Waldo, D. R., Smith, L. W., \& Cox, L. E. (1972). Model of cellulose disappearance from the rumen. Journal of Dairy Science, 55(1), 125-129. doi: 10.3168/jds.S00220302(72)85442-0

Williams, K. T., Weigel, K. A., Coblentz, W. K., Esser, N. M., Schlesser, H., Hoffman, P. C.,... Akins, M. S. (2019). Effect of diet energy density and genomic residual feed intake on pre-bred dairy heifer feed efficiency, growth, and manure excretion. Journal of Dairy Science, 102(5), 1-10. doi: 10.3168/ jds.2018-15504 
